\title{
Notes on Operations Employing Usage Data to Plan for an E-book Collection
}

\section{Strategies and Considerations}

\author{
Forrest Link, Yuji Tosaka, and Cathy Weng
}

The authors created a research method to identify local users' needs and explored how well currently available e-book content might meet those needs. Using circulation records, interlibrary loan (ILL) requests, and in-house use as a gauge of patron demand during a three-year period, the study compared these records to e-book offerings from the major aggregators. The resulting data were analyzed by subject and publication date. The authors found that e-book content that might meet users' needs was not uniformly distributed across disciplines and that more recent publications were more likely to have e-book equivalents. The highest percentage of e-book equivalents was for titles requested via ILL, suggesting that this might be the best place to begin e-book collecting. The results suggest that e-books may meet only a fraction of the demand for monographic scholarly output and that libraries cannot yet rely on e-book content to entirely supplant print, although e-book coverage is growing dramatically.

Forest Link (linkf@tcnj.edu)is Acquisitions Librarian, Yuji Tosaka (tosaka@tcnj.edu) is Cataloging/Metadata Librarian, and Cathy Weng (weng@tcnj.edu) is Head of Cataloging, The College of New Jersey, Ewing, New Jersey.

Submitted March 30, 2012; tentatively accept April 23, 2012, pending modest revision; revision submitted June 11,2012, and accepted for publication.

The authors are grateful to YBP and Coutts for their assistance in data gathering.
R ecently, libraries — particularly academic libraries — have been grappling with $\mathbf{Z}$ issues surrounding e-book acquisitions and collection development. Starting as bundled packages with rather restrictive lending models as first promoted by NetLibrary in the late 1990s, e-books have become more patron-friendly through flexible lending arrangements and have become more acquisitions-friendly through single-title offerings.

In contrast to their swift adoption of e-journals, academic libraries were slow to integrate e-books into the library collections. Barriers to e-book acceptance included libraries' and users' initial unfamiliarity with e-books, slow standardization of e-book technical platforms, lack of a sustainable e-book purchasing model, uncertain circulation policies, and limited discovery and delivery options. ${ }^{1}$ Despite these hurdles, the development of e-book collections has emerged as a growing trend among libraries because the new medium provides "added functionality over print versions." ${ }^{2}$ This added functionality includes constant availability, remote access, and full-text searching. E-books require no shelf space or reshelving. They can never be lost, stolen, damaged, or overdue. ${ }^{3}$

In the late $2000 \mathrm{~s}$, a breakthrough in creating a viable e-book purchase model became one important motivation for libraries to develop large-scale e-book collections. Print book vendors, working with publishers and e-books aggregators, began to incorporate e-books into their ordering databases. This was a 
considerable improvement over the previous practice of negotiating and managing separate licenses with individual e-book providers or publishers. ${ }^{4}$

More recently, publishers, aggregators, and vendors have moved to promote patron-driven acquisitions (PDA), also called demand-driven acquisitions, by capitalizing on their enhanced platform tools and ondemand availability. In this just-in-time model, which aims to serve as an alternative to the traditional just-in-case model, patrons can enjoy immediate gratification while librarians can continue to broadly shape their collections behind the scenes. Studies have shown that a large percentage of library print materials acquired through traditional means do not circulate. ${ }^{5}$ According to Hodges, Preston, and Hamilton, the unused books collected using the just-in-case model are "viewed as waste because it costs to maintain and does not produce a product." ${ }^{\prime 6}$ In contrast, studies have shown that materials procured based on user demand have higher post-purchase usage. ${ }^{7}$ As a result, libraries adopting the PDA model should be able to obtain a better return on their investment in book expenditures as books purchased on demand are used more frequently and by more users.

As the perceived user-demand has led an increasing number of libraries to incorporate e-books into their collections, the issue of perpetual access of e-resources-which has been widely discussed since e-journals were first introduced in the academic community—remains valid and an important consideration in e-books collection development. Libraries need to find a balance between meeting user needs by providing current imprints in userpreferred formats and managing the challenge of ensuring continued access to subscribed or purchased e-content for the future. ${ }^{8}$

E-book technology has advanced at a remarkable pace and academic users have shown a rapidly expanding interest in e-books. While e-book collecting offers advantages to academic libraries faced with challenges of space and escalating patron demand, surprisingly little attention has been paid to the limitations of e-book coverage. ${ }^{9}$ That is, broad areas of monographic publishing still remain untouched by the rapid advances in e-book usability and availability. How can libraries make informed decisions about e-book purchasing so that money can be wisely spent to meet user needs?

In response to the growth in electronic publishing and e-book collecting, The College of New Jersey (TCNJ) Library undertook a study to determine how e-book acquisition could best meet the needs of users. This paper examines and analyzes titles used by TCNJ Library users and the availability of their electronic counterparts offered by e-book providers. The purpose of the study was to determine whether and how e-book content could be adopted as a viable alternative to print. This paper also introduces practical methods to measure local user needs as a baseline against which to evaluate content offered by e-book providers. In addition, the paper will help shed light on the current e-book marketplace and contribute to a better understanding of the promises and limitations of e-book publishing for academic libraries. The current study sought to answer the following questions:

- Can monographic e-content offered by providers supplement or even supplant local print usage?

- Is e-book acquisition able to meet the needs of users? How?

\section{Literature Review}

\section{The Evolving Role of E-Books}

In a 2001, the California Digital Library Ebook Task Force conducted a survey of fourteen large academic libraries to learn about their e-book experiences. ${ }^{10}$ At that time, some libraries believed that "the role of e-books was not to replace print but to serve as a duplicate copy." ${ }^{11}$ Studies conducted by Columbia University (in 1997) and the University of Rochester (in 2001) on user perceptions and their use of e-books found that users were receptive to using electronic reference books for quick answers but less interested in reading electronic versions of academic books. ${ }^{12}$ An ebrary survey in 2007 also indicated that users found e-books difficult to read, e-book platforms difficult to use, and training in using electronic resources in short supply. ${ }^{13}$ E-book suppliers had yet to develop a satisfactory purchase model that would make bulk e-book purchases easy for libraries. ${ }^{14}$ Not until the mid-2000s did e-books start to gain traction with academic library users and become an important academic library service. ${ }^{15}$

User perception of e-books also can be seen from usage analyses. Findings of recent usage studies of e-books have varied. Studies conducted at the University of Idaho and Oakland University documented low e-book use. ${ }^{16}$ In contrast, a Duke University study found that more e-books than print books were used. ${ }^{17}$ In determining what users need, investigating whether, for any given title, the electronic version is used more heavily than the print version is important. A 2010 report of a study at the Texas A\&M University Libraries compared use of e-books and their print equivalents in the physical sciences and technology. ${ }^{18}$ The study results suggested strong user preference for e-book versions:

For NetLibrary, the top 10 science e-books were used over six times more than the [equivalent] print books, and the top chemistry e-books 
were used over 3 times more than their print counterparts. For ebrary, the top 17 science e-books were used at least 17 times more than the same print books. In Safari, the top 10 computer science e-books were used 207 times more than their print counterparts. $^{19}$

\section{ILL Purchase of Demand and PDA of E-Books}

The implementation of patron-initiated purchases by libraries also has changed the landscape of library collection development. The 2008-9 ARL statistics report documented a sharp increase in ILL borrowing during the previous two decades. ${ }^{20}$ This clearly indicated that "local collections do not meet needs adequately." ${ }^{\prime 21}$ In response to the unmet needs, purchase-on-demand (POD, sometimes called patron-initiated purchase), based on interlibrary loan (ILL) requests, was adopted by several libraries in the early 2000 s. $^{22}$ Some librarians have been skeptical of using patron-initiated ILL purchases as a way to develop library collections. The fear was that such a practice would result in unbalanced and possibly expensive collections of little use. ${ }^{23}$ However, research has proven otherwise. Recent studies have presented consistent findings that the high percentage of the titles ordered through ILL POD was appropriate for library collections. ${ }^{24}$ Further, the circulation rate of the ILL POD titles outperformed that of titles acquired via the conventional system. ${ }^{25} \mathrm{~A}$ survey performed at Oregon State University also indicated high patron satisfaction with their Buy Request pilot initiative. ${ }^{26}$ As a result, the Oregon State University Library has adopted it as a permanent service. Tyler and colleagues incorporated usage into their measurement of the cost of books (i.e., books become more cost-effective when they circulate more times) and found that the cost per title of ILL POD books was lower than books purchased through traditional means because of their higher circulation rates. ${ }^{27}$ Patron-driven acquisitions programs have proved worthwhile on many levels, such as "cost-effective collection development; user satisfaction; high subsequent circulation; and flexibility in meeting local constraints for price, content, and processing." 28

With e-books gaining popularity, along with the success of the print-based ILL POD model, libraries began to extend the ILL POD service by adopting PDA of e-books. The low circulation rate of print monographs and the rising number of ILL requests indicate an unmet demand among academic users. ${ }^{29}$ Many libraries have implemented PDA of e-books with the goal of better meeting user needs in a timely manner. ${ }^{30}$ Price and McDonald found evidence of heavy post-purchase usage of e-book titles acquired via PDA programs in their study-further justification for investing in an e-book collection. ${ }^{31}$ They found that user-selected e-books were used two to five times more often than librarian-selected e-books. Their findings also indicated fewer unused titles in their user-selected e-book collections.

\section{Coverage of E-Book Providers}

Despite the rapid development of the e-book market, is completely replacing new acquisitions of print materials with e-books wise? Can e-book suppliers fulfill academic libraries' needs in supporting campus teaching and learning? Price and McDonald conducted an e-book study in which they compared the print book purchases of five academic libraries with the content currently made available by four major e-book aggregators. ${ }^{32}$ Their study showed that 70 percent of print titles purchased by the participating libraries in 2006 and 2007 were not available from any of the aggregators included in the study. The average matching rates between actual library purchases and the content available from the aggregators was low, ranging from 5 to 25 percent. Inspired by this study, Pomerantz undertook a similar study at Adelphi University with an emphasis on nursing and business print titles acquired by the library. ${ }^{33}$ Her study had similar findings: less than one-third of print books had e-book equivalents available from aggregators.

These studies focused on the availability of e-book equivalents of current print purchases in academic libraries. However, no study thus far has investigated whether libraries can meet current user needs with a greater reliance on e-book acquisitions. Meeting patron needs is more than a matter of determining whether e-book equivalents of the totality of current in-house collections are available. User needs are best reflected in actual materials used. By establishing the levels of e-book equivalency for materials that have been circulated, used in-house, or requested through ILL, academic libraries can ascertain whether the demand for those materials can be met through the acquisition of e-book content.

\section{Environment}

The College of New Jersey is a medium-sized institution with about 6,000 full-time enrollees, primarily undergraduates. The College has seven schools and offers approximately fifty major areas of study. TCNJ Library holds nearly 600,000 monographs as well as significant periodicals and media collections in various formats. The library's current e-book collections include approximately 4,000 NetLibrary (now EBSCOhost ebooks) 
titles purchased through a local consortium and more than 200 electronic reference titles.

\section{Research Method}

In the design of the present study, the authors sought meaningful measurements of TCNJ Library user needs. The study was based on the assumption that user needs are reflected in three areas: titles owned by the library and circulated, titles not owned by the library and requested through ILL, and titles owned by the library and used in-house. The authors collected and analyzed three areas of usage data to identify their availability in e-book format offered by major e-book providers. By so doing, the authors aimed to evaluate how current user needs reflected in these library use measures could be met by available e-book equivalents and how such data could be used to project and inform future collection development policy in the digital environment.

For the present study, the authors measured local usage of print materials by assessing three types of data:

1. Circulation transaction logs for the General Collection (i.e., circulating print monographs)

2. ILL book request logs (i.e., books borrowed via ILL)

3. In-house usage data for the General Collection.

The process of assembling these data, which were then sent to two major e-book vendors, YBP and Coutts, for matching against available e-books, is described below.

\section{Circulation Activity}

The authors turned to the local Voyager system to extract the first data source-circulation transaction logs of monographs in the General Collection for the period of July 2008-May
2011. The circulation transactions provided sufficient information about the checkouts of print titles and allowed the authors to examine the extent to which e-book formats could be expected to satisfy current circulation needs. The data for June 2011 were not included because they were not yet available at the time of data collection for the present study. The same limitation applies to the other two data sources discussed below.

To obtain an accurate circulation count for the print collections, the authors first used Microsoft Access queries to clean up the original circulation transaction logs for the study. While the circulation logs listed all individual items loaned to users during the three-year period, the unit of analysis in this study had to be titles rather than items. If users had checked out multivolume titles also available in e-book format, the unadjusted itemlevel circulation data might well affect e-book availability rates because such titles would be counted multiple times rather than once. For that reason, the authors treated item records for a multivolume title loaned on the same day as a single circulation transaction. Circulation transactions were counted as separate cases, however, when duplicate copies were loaned on the same day or when multivolume titles were checked out more than once in a single day. The authors removed titles lacking ISBNs from the data set because the vendors could not readily supply reports about the electronic counterparts of the print titles without ISBN data.

\section{ILL Activity}

To obtain ILL book requests, the authors extracted the ILL data for the same three-year period from the OCLC Usage Statistics system (WorldCat Resource Sharing). The authors used Access queries to deduplicate the ILL data using OCLC control numbers. This produced a final list of unique titles requested via ILL.

\section{In-House Use}

Finally, the authors used the "historical browse" data recorded in the local Voyager system to collect records of circulating monographs used in-house (i.e., General Collection titles taken off the shelves and left on tables or in other places). These data were recorded under TCNJ Library's long-standing policy requiring that barcodes of books used in-house be scanned in Voyager before being reshelved. This scan triggers "historical browse" transactions in the system. The inhouse use data collected have some limitations. The Voyager system does not register the "historical browse" transaction date, and pinpointing when particular in-house uses were recorded is not possible, meaning the data include print titles that may have been used before the timeframe of this study. Therefore, for data collection purposes, the authors only used in-house use data on titles that were cataloged during the three-year study period. Thus titles cataloged before the study period but used during that time were not included. Also, because TCNJ Library does not specifically ask users not to reshelve used items, books used in-house and reshelved by users are not tracked. Furthermore, without data for in-house use dates, determining when individual items in a multivolume title might have been used or whether they were used together or separately is impossible. The authors concluded that the number of such cases was small, constituting less than 3 percent of the entire "historical browse" data and not significant enough to skew the data. Thus the historical browse data extracted from the Voyager system do not provide a complete picture of in-house use of library materials. Regardless, because the goal was to determine the e-book availability of heavily used 
titles, the authors believed that historical browse data would provide helpful usage information.

\section{Results and Analysis}

Local Data Results

\section{Circulation Transactions}

According to the Voyager data, TCNJ Library had 98,586 circulation transactions; this was reduced to 97,922 transactions when 664 titles without usable publication dates were removed. The upper panel of table 1 presents the publication dates and the percentages of all circulation transactions during the three-year period. Immediately noticeable is the higher patron use of more recent publications. This strong association between publication date and circulation is consistent with the findings from several classic collection-use studies summarized by Lancaster. ${ }^{34}$ More than one-third of circulation transactions were for titles published since 2000. When the timeframe was broadened to 1990-2011, titles published during this period accounted for 60.8 percent of all circulation during the past three fiscal years. Because of this effect of publication dates on circulation, the analysis of e-book availability focused on publications since 1990. This approach also was appropriate because of the limited availability of older titles in digital format from the aggregators.

The lower panel of table 1 illustrates how circulation data were used to identify the core collection of heavily used titles for the present study. Titles with three or more checkouts accounted for 34.9 percent of all circulation transactions, although they amounted to 13.3 percent of all unique titles checked out during this period. In the group of titles circulating three or more times, the most heavily used title circulated fifty-four times during the three-year period. Such high

Table 1. Circulation Transactions

Publication Dates of Circulating Items

Number of

Percent of

Publication Date Range

Circulation Transactions

Total Circulations

$-1939$

1,719

1.8

1940-89

36,696

37.5

1990-99

24,770

25.3

2000-2011

34,737

35.5

Total

97,922

100.0

Circulation Transactions for Unique Titles

$\begin{array}{ccc}\begin{array}{c}\text { Number of } \\ \text { Circulations per Title }\end{array} & \begin{array}{c}\text { Number of Unique } \\ \text { Titles Circulated }\end{array} & \begin{array}{c}\text { Percent of Total Unique } \\ \text { Titles Circulated }\end{array} \\ 3 \text { or more } & 8,069 & 13.3 \\ 2 & 11,731 & 19.4 \\ 1 & 40,692 & 67.3 \\ \text { Total } & 60,492 & 100.0\end{array}$

checkout counts might be due to the Voyager system not recording historical changes in item locations, meaning that the circulation logs for the General Collection include titles that have been transferred from other locations. Titles with exceptionally frequent circulation could have been course-related materials that once were available on the Reserve Desk for short-term loans. However, because identifying with precision what proportion of the most heavily used titles had been relocated to the General Collection was not possible, all circulation transactions recorded were treated as valid data for this study. The authors also felt comfortable disregarding titles with extremely high checkout counts as outlier cases because their number was too negligible to have any significant effect on the analysis. For example, only 0.4 percent of the circulated titles had been checked out more than nine times (i.e., three times per year on average) during the period under consideration.

Using three checkouts as the threshold for selecting the circulation data resulted in a data set of 8,069. After records without ISBNs were removed, a final data set of 6,960 titles with ISBNs was sent to the vendors. Three checkouts was considered a reasonable threshold for this study because the authors intended to investigate the e-book availability of print titles heavily used at TCNJ Library and because three user views often are used as a threshold for triggering PDA e-book purchase, a new service being considered for adoption in TCNJ Library. Removing records without ISBNs should have no significant effects on the vendor data analysis because these records are mostly for older publications and e-book publishing has focused on newer titles.

\section{ILL Requests}

As shown in table 2 , the library received 5,166 ILL book requests with publication date information supplied by the OCLC system. Two ILL requests without publication dates supplied are excluded from the upper panel. The ILL book requests were reduced to 3,821 unique titles when the authors used Access queries to de-duplicate the ILL data using OCLC control numbers.

The ILL data also revealed the importance of newer publications in 
meeting user needs. The association between publication dates and ILL requests was even more prominent than that seen in the circulation data. Table 2 shows that nearly two-thirds of ILL requests were for titles published since 2000. This percentage was almost double the circulation data for the same period. When preparing the ILL data for vendors to check for e-book equivalents, the authors found that using three requests for unique titles as the threshold, as was done for circulating titles, would not be a viable approach because only 3.4 percent of ILL items were requested three times or more while nearly 70 percent of ILL titles were requested only once (see table 2). Furthermore, past research suggests that ILL requests clearly represent unmet user needs. ${ }^{35}$ Because the authors also wanted to find the extent to which the availability of e-books on market could meet all local ILL needs, after removing 119 titles without ISBNs from the initial data set of 3,821 titles, all unique ILL titles with ISBNs requested $(3,702)$ were sent to the vendors as opposed to the checkout threshold of three for the circulation data.

\section{In-House Use}

As shown in table 3, the library had a total of 9,368 in-house usage transactions for circulating items in the General Collection that were cataloged during the three-year study period. Those transactions amounted to 4,529 unique items.

The in-house use data revealed that circulating print materials with four or more uses accounted for more than one-third of all in-house browsing, which made up 12.3 percent of all unique items used in-house. To ensure comparability, the authors took a similar approach to that used to select the subset of core titles in the circulation data and set four counts of in-house use as the threshold for selecting the subset of core titles used heavily

Table 2. ILL Requests

\begin{tabular}{ccc}
\hline & \multicolumn{2}{c}{ Publication Dates of ILL Requests } \\
Publication Date Range & Number of ILL Requests & Percent of Total ILL Requests \\
1961-89 & 595 & 11.5 \\
$1990-99$ & 1,267 & 24.5 \\
$2000-2011$ & 3,304 & 64.0 \\
Total & 5,166 & 100.0
\end{tabular}

ILL Requests for Unique Titles

Number of ILL Requests per Title Number of Unique Titles Percent of Total 3 or more 130 Unique Titles

$$
2
$$$$
130
$$$$
3.4
$$

1,041

27.2

1

2,650

69.4

Total

3,821

100.0

\begin{tabular}{c|cc|cc}
\hline \multicolumn{1}{l}{ Table 3. In-House Use } & \multicolumn{3}{l}{} \\
\hline $\begin{array}{c}\text { Number of } \\
\text { In-House } \\
\text { Uses per Title }\end{array}$ & \multicolumn{2}{|c|}{ In-House Uses } & Unique Titles Used In-House \\
4 or more & Titles & Percent & Titles & Percent \\
3 & 3,279 & 35.0 & 557 & 12.3 \\
2 & 1,371 & 14.6 & 457 & 10.1 \\
1 & 2,406 & 25.7 & 1,203 & 26.6 \\
Total & 2,312 & 24.7 & 2,312 & 51.0 \\
\hline
\end{tabular}

in-house. The authors opted for four or more in-house uses because of the similarity in percentages with that of three or more circulations. Of those 557 titles used in-house four or more times, 32 did not have ISBNs, and the remaining 525 titles with ISBNs were selected for the study sample data.

\section{Vendor Data Results}

The authors prepared the three data sets reflecting the different aspects of local print materials use and sent them to two e-book providers: YBP and Coutts. YBP is the main book vendor for TCNJ Library and has partnered with three of the main aggregators of academic e-book titles. Coutts is the academic arm of Ingram Content Group, which owns the MyiLibrary platform. The vendors then ran
TCNJ Library's usage data against their e-book title lists of the four aggregators to locate e-book equivalents of the print titles used by TCNJ users. YBP provided e-book data from three aggregators: ebrary, EBL, and EBSCOhost. Coutts provided MyiLibrary e-book data. Additionally, YBP noted which titles were being offered by their publisher partners outside of the three aggregator platforms and grouped these under the rubric "Publisher Direct," a term the authors have kept in reporting results. The authors also believe that the four aggregators whose data were used in the present study are the major suppliers of e-books in the academic library market. The sample data studied, although not exhaustive, are considered to be representative of e-book offerings currently available to academic libraries. 
Table 4 Availability of E-Book Equivalents

\begin{tabular}{|c|c|c|c|c|c|c|}
\hline \multicolumn{7}{|c|}{ Vendors' Raw Data Summary } \\
\hline Sources of E-Books & $\begin{array}{c}\text { Number of } \\
\text { Circulating Titles } \\
\text { Available }\end{array}$ & $\begin{array}{l}\text { Percent of Total } \\
\text { Circulating Titles }\end{array}$ & $\begin{array}{l}\text { Number } \\
\text { of ILL Titles } \\
\text { Available }\end{array}$ & $\begin{array}{l}\text { Percent of } \\
\text { Total ILL Titles } \\
\text { Requested }\end{array}$ & $\begin{array}{l}\text { Number of } \\
\text { In-House } \\
\text { Use Titles } \\
\text { Available }\end{array}$ & $\begin{array}{c}\text { Percent of Total } \\
\text { In-House Use } \\
\text { Titles }\end{array}$ \\
\hline EBL & 796 & 11.4 & 545 & 14.7 & 115 & 21.9 \\
\hline ebrary & 997 & 14.3 & 658 & 17.8 & 133 & 25.3 \\
\hline EBSCOhost & 1,189 & 17.1 & 656 & 17.7 & 134 & 25.5 \\
\hline MyiLibrary & 744 & 10.7 & 546 & 14.7 & 107 & 20.4 \\
\hline
\end{tabular}

E-Book Equivalents Available by the Number of Vendors

\begin{tabular}{|c|c|c|c|c|c|c|}
\hline \multirow[b]{2}{*}{$\begin{array}{l}\text { Number of Sources } \\
\text { Providing Each Title }\end{array}$} & \multicolumn{2}{|c|}{$\begin{array}{c}\text { Circulating Titles } \\
\qquad 1,456\end{array}$} & \multicolumn{2}{|c|}{$\begin{array}{c}\text { ILL Requested Titles } \\
869 \\
\end{array}$} & \multicolumn{2}{|c|}{$\begin{array}{c}\text { In-House Use Titles } \\
165\end{array}$} \\
\hline & Number of Titles & $\begin{array}{c}\text { Percent of } \\
\text { Available Titles }\end{array}$ & $\begin{array}{c}\text { Number of } \\
\text { Titles }\end{array}$ & $\begin{array}{c}\text { Percent of } \\
\text { Available Titles }\end{array}$ & $\begin{array}{c}\text { Number of } \\
\text { Titles }\end{array}$ & $\begin{array}{c}\text { Percent of } \\
\text { Available Titles }\end{array}$ \\
\hline 1 & 405 & 27.8 & 210 & 24.2 & 33 & 20.0 \\
\hline 2 & 244 & 16.8 & 113 & 13.0 & 18 & 10.9 \\
\hline 3 & 341 & 23.4 & 187 & 21.5 & 37 & 22.4 \\
\hline 4 & 424 & 29.1 & 318 & 36.6 & 75 & 45.5 \\
\hline 5 & 42 & 2.9 & 41 & 4.7 & 2 & 1.2 \\
\hline
\end{tabular}

\section{Circulation Titles}

Of the 6,960 circulated titles sent to the vendors, 20.9 percent were available in an e-book equivalent from at least one source (see table 4). Of these, the greatest number (17.1 percent) was available from EBSCOhost. Only 1.5 percent were supplied by publishers directly outside of any aggregator platform (i.e., "Publisher Direct"). A considerable number of titles were provided by multiple suppliers. As shown in table 4 , more than 55 percent of the e-book equivalents identified were available from three or more sources.

When examining the results of the sample data on the basis of publication date of the original hardcopy edition, the authors found that, unsurprisingly, the number of equivalent titles has increased steadily over time. As shown in figure 1, newer titles have a greater percentage of e-book equivalents (although EBSCOhost, formerly NetLibrary, uniquely handled some older and non-academic titles as well, most likely because of their early entry into the e-book marketplace). For titles with an imprint of 1990, only 5.1 percent were also available as an e-book. The data showed a steady yearly increase in the percentage of e-book equivalents that matched the circulation needs of TCNJ Library. For 2009 imprints, the percentage rose to 38.1 percent. The authors suspect that the apparent decline in e-book equivalents for the most recent year may be a result of delays between the release of print and electronic editions that reflect publisher marketing strategies and not reductions in output.

Moving from an analysis of raw quantities of e-book equivalents, one may refine the data by looking at the list of titles from a subject coverage perspective. This is especially valuable to special libraries or libraries considering e-book collecting by discipline. A subject analysis of e-book equivalents based on the Library of Congress (LC) call numbers associated with the circulation data found that e-book coverage was not consistent across subjects (see figure 2). History (LC classes D-F) and the social sciences (LC classes $\mathrm{G}-\mathrm{K}$ ) were more heavily represented at 22.5 percent and 25.3 percent respectively, while art (LC class N) and music (LC class $\mathrm{M}$ ) were underrepresented at 12 percent. 


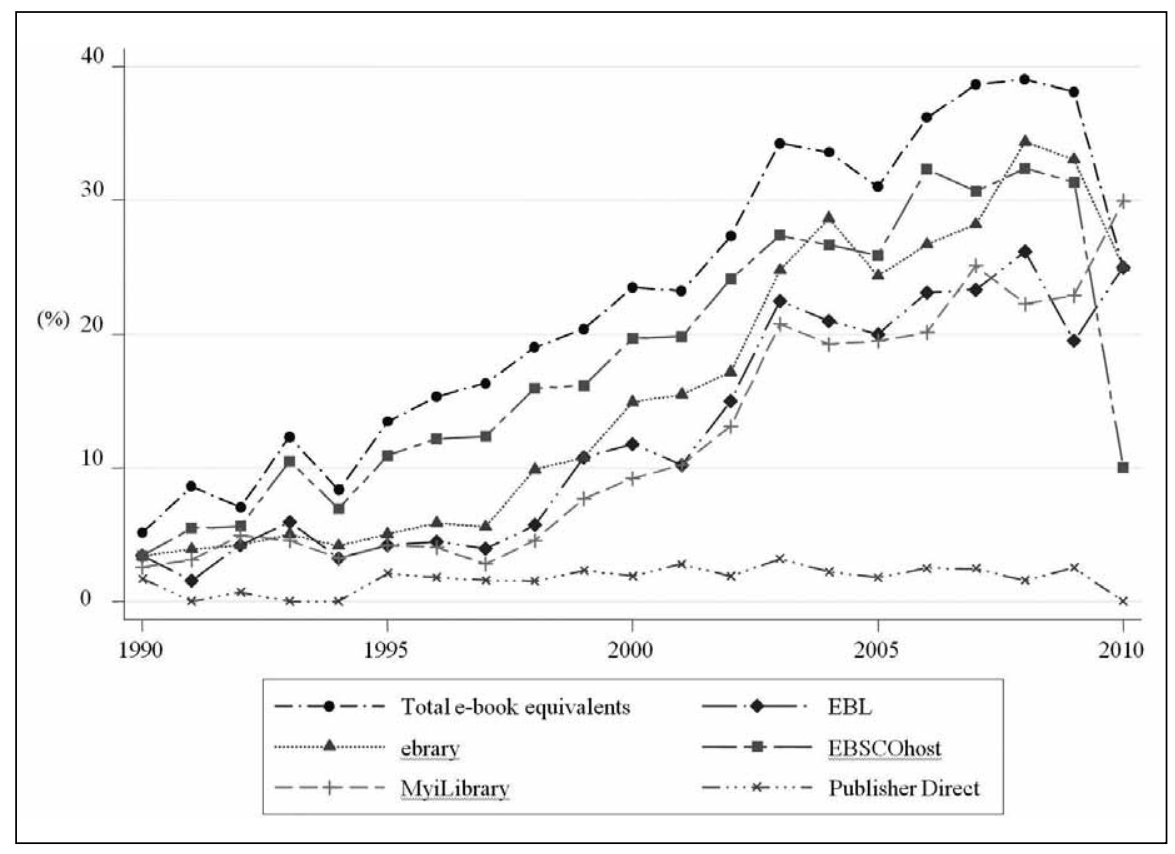

Figure 1. Circulation Needs Met by Publication Date

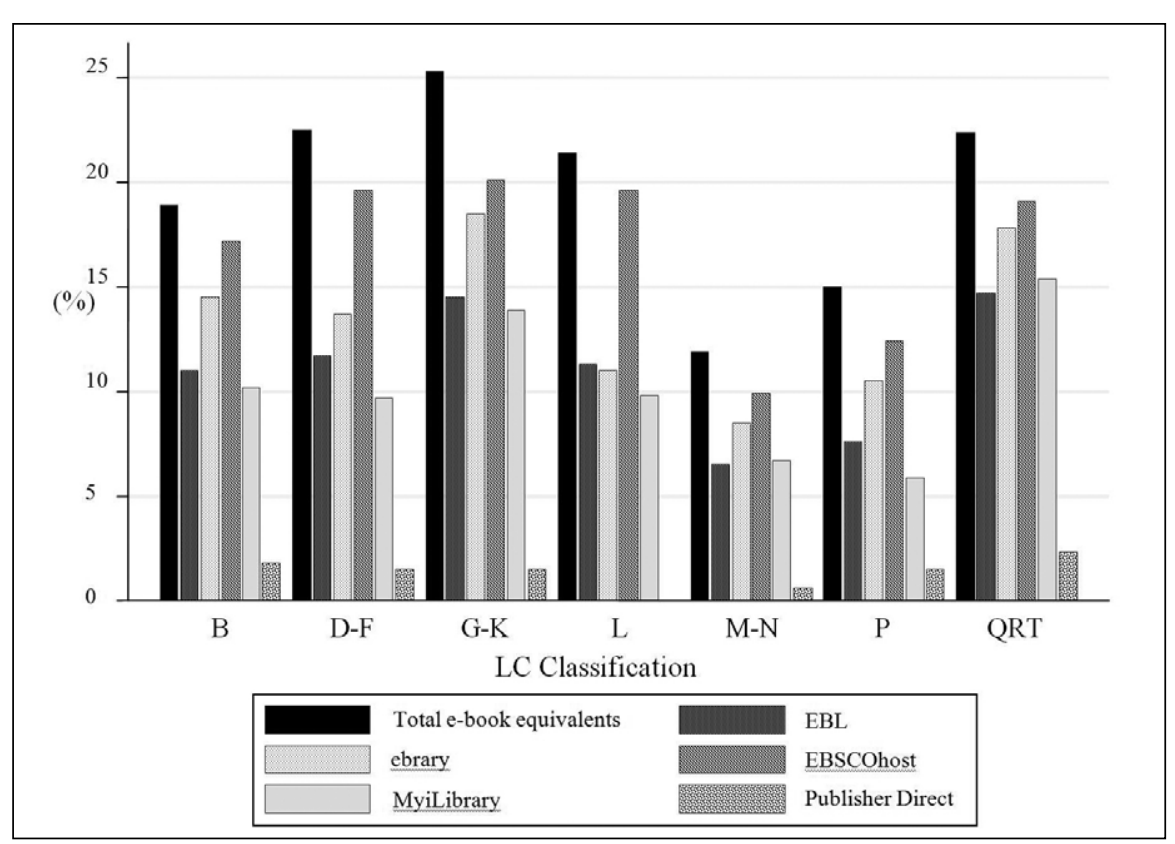

Figure 2. Circulation Needs Met by Subject Area

\section{ILL Titles}

For titles borrowed via ILL, out of the 3,702 titles checked by the vendors, 23.5 percent were available as an e-book from at least one source. Ebrary provided the highest percentage (17.8) in this category, with EBSCOhost providing a very similar percentage (17.7) (see table 4). As seen in the circulated titles sample, coverage overlaps across suppliers. Nearly 63 percent of the e-book equivalents identified were available from three or more sources (see table 4).

The study results demonstrated that the currency of publication date was closely associated with user needs for ILL materials to a greater degree than was the case for circulated titles (see table 2). As shown in figure 3, this demand for newer titles was matched by a higher level of total e-book equivalents available exceeding 50 percent for 2011 imprints. Interestingly, this result contrasts with the apparent decline in e-book equivalents available for circulating print titles since 2010 (see figure 1). The finding appears to be inconclusive, however, possibly skewed by the small size of the 2011 data for titles requested via ILL at the time of data collection. If this difference is not a random result of data size variation, identifying its potential internal and external causes, such as current selection decisions at TCNJ Library and publisher marketing strategies, would be valuable.

Looking at subject needs met by e-book equivalents, the authors found that coverage continued to be inconsistent across subjects, but that the levels of e-book equivalents were generally higher than that found in the circulation data (see figure 4). In LC class B (philosophy, psychology, and religion), for example, nearly 30 percent of the titles TCNJ Library requested on ILL were also available as e-books. Social sciences (LC classes G-K) and hard sciences (LC classes QRT) were not far behind, each surpassing 25 percent. As with the results for circulation data, art and music titles (LC classes M-N) had the lowest rate of e-book equivalents at 8.2 percent.

\section{In-House Use Titles}

Because the data collection method employed by the authors selected the titles in this category based on the date each was cataloged, this sample was naturally biased toward newer 
books. Unlike tables 1 and 2, table 3 does not include publication date range data because the in-house use data were extracted based on the past three-year cataloging dates; 90.9 percent of in-house use for the current study was for titles published since 2000. As expected, the rate of e-book equivalents was highest in this area because e-book equivalents are more common for newer titles. Of the 525 circulating monograph items in the General Collection heavily used inhouse, 31.4 percent were available as an e-book from at least one source (see table 4). Again, EBSCOhost provided the highest percentage (25.5), with ebrary providing a very similar percentage (25.3). Nearly 70 percent of the e-book equivalents identified were available from three or more sources (see table 4).

Likewise, in terms of subject needs met, e-book equivalents for in-house use items, on the whole, exceeded the levels found in the circulation and ILL samples (see figure 5). Like the results for circulation and ILL, e-book equivalent titles were not evenly distributed across subject areas. Philosophy, psychology, and religion (LC class B) were most heavily represented (exceeding 40 percent) while education (LC class L) lagged at just over 20 percent.

\section{Discussion}

Based on the results obtained at TCNJ Library, the authors found that e-books are rapidly gaining ground as alternate editions of titles that patrons have borrowed, requested via ILL, or used in-house. Admittedly, this study may slightly under-report the proportion of e-book equivalents available for print titles because the authors obtained data only through YBP and Coutts (though they are currently two major e-book vendors in the academic library market). However, the study found that e-book equivalents are a growing segment of book publishing and that

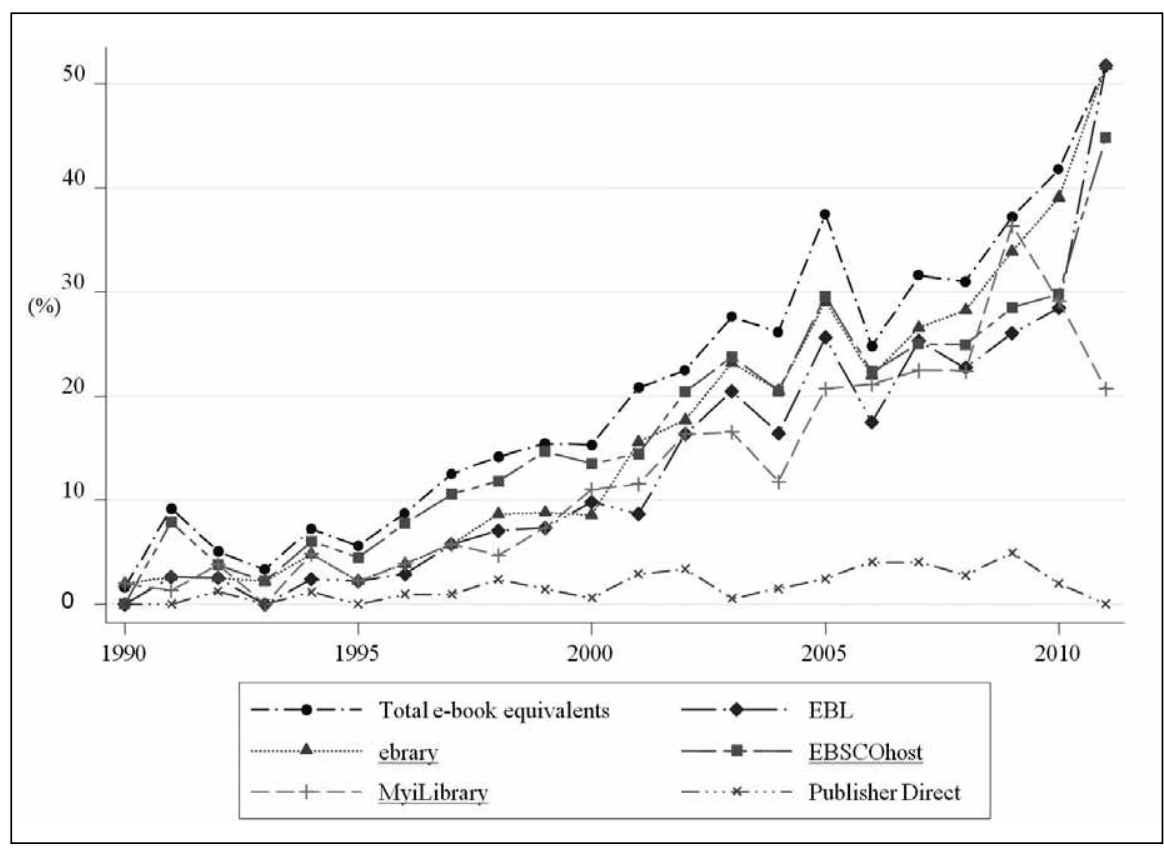

Figure 3. ILL Needs Met by Publication Date

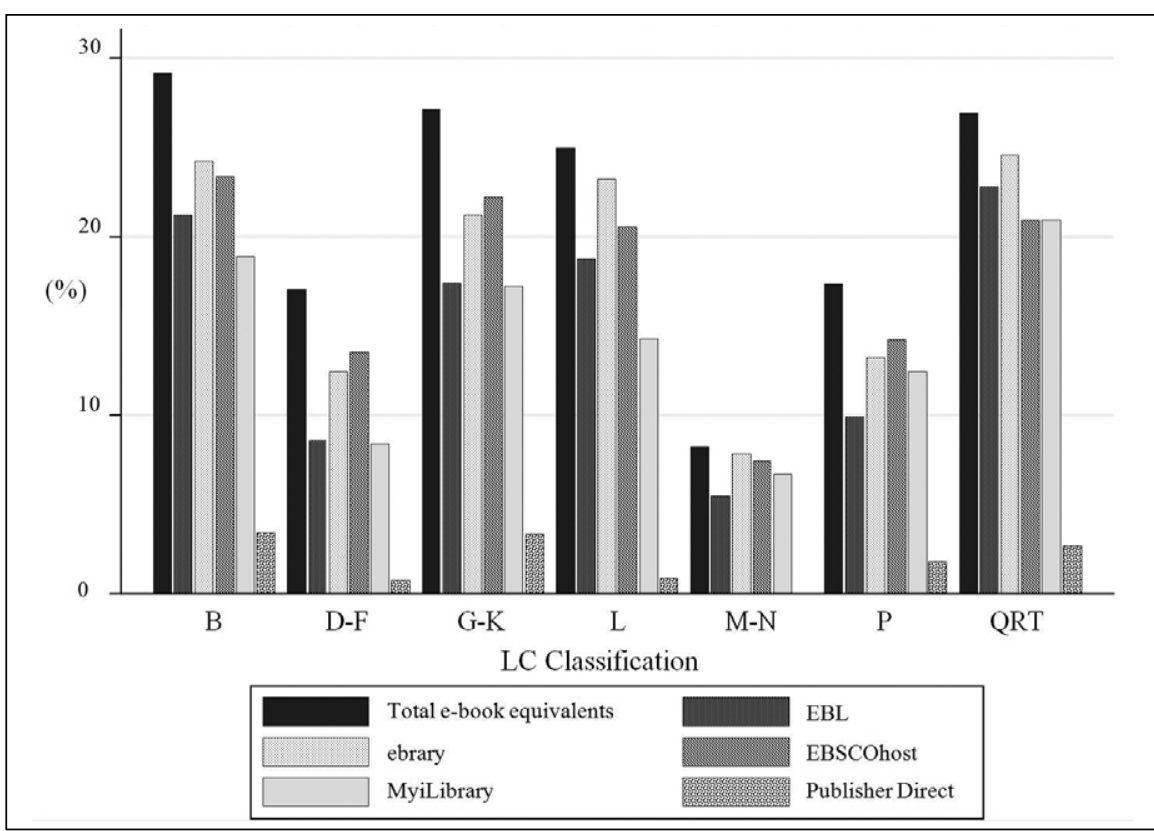

Figure 3. ILL Needs Met by Subject Area

they might fill an increasing percentage of library needs. These needs, however, are not met proportionately across subject areas. At TCNJ Library, e-book equivalents meet circulation needs better in the social and hard sciences and less well in the arts and literature. Newer (but not yet newest) titles have the best chance of being represented in e-book editions. This pattern is repeated in meeting ILL needs. Overall, the results suggest that e-books are still to be considered as a supplemental medium. 


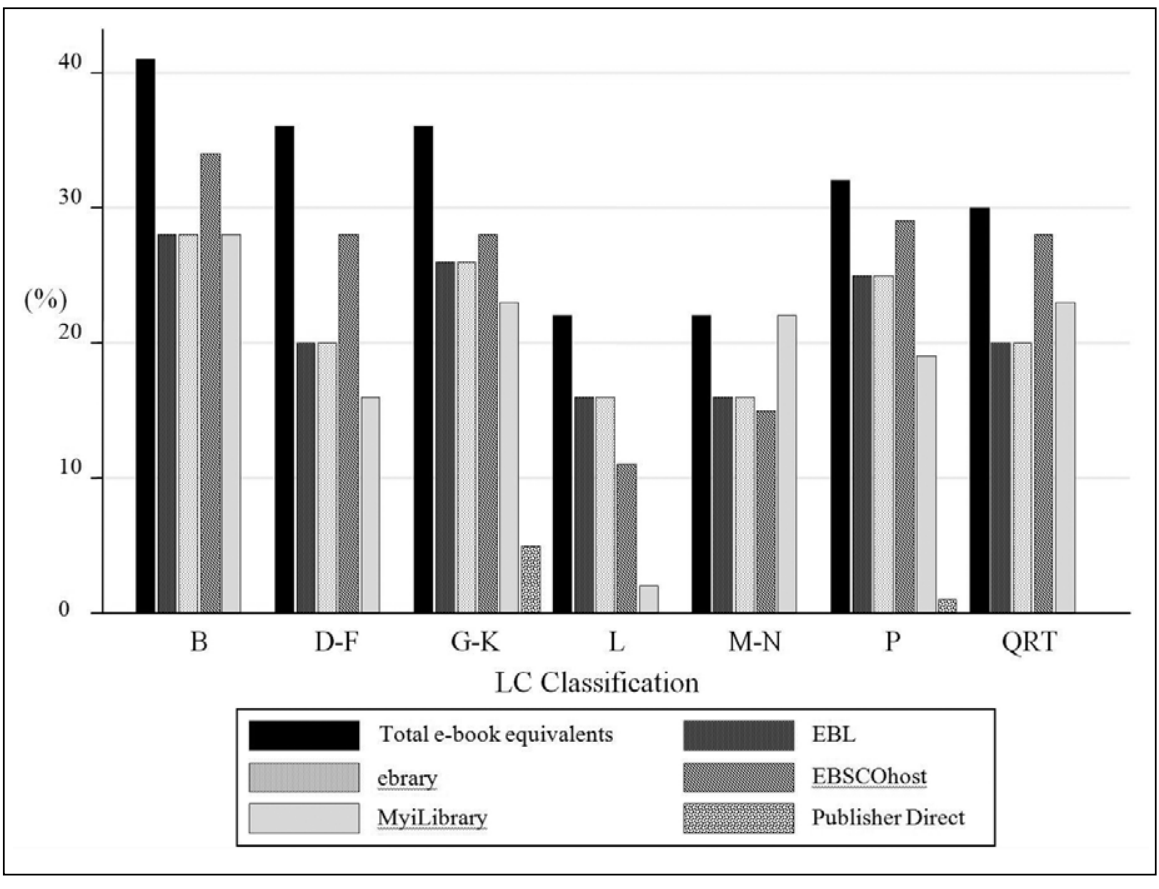

Figure 5. In-House Usage Needs Met by Subject Area

In seeking e-book equivalents for more recent titles, the choice of aggregator appears relatively unimportant because, based on the levels of common coverage, the existence of an e-book equivalent seems to hinge on choices made at the publisher level. Nevertheless, the results show that purchasing from aggregators instead from individual publishers is more effective. Also, because of the high levels of e-book equivalents to ILL requests noted in this study (and their near-immediate availability), the study results suggest that TCNJ Library might start collecting e-book editions of titles requested via ILL.

Collections and circulation patterns of various institutions are different and this study reflects only the usage patterns encountered at TCNJ. Usage records directly relate to the curriculum and research needs of an institution. In no way should the study results be taken as an evaluation of the capabilities of the aggregators examined or extrapolated to other academic library collections. While the method used in this study is sound and will be useful to other libraries, results may vary because of the uniqueness of local collections and user needs. Indeed, a very interesting topic for future studies would be a comparison of how the availability of e-book equivalents may vary across different libraries. Notwithstanding the aggregators' claims of publisher coverage, investigating how completely and how promptly a given publisher offers its catalog in e-book format would be instructive. Future analyses also might inquire into the e-book practices of particular publishers whose titles are heavily circulated.

Another limitation of the current study is that it was the authors' intent to exclude the usage data of the current e-book collections-mostly some 4,000 NetLibrary titles-at TCNJ Library. This exclusion was because e-book usage data, involving such metrics as the number of downloads and the length of time an e-book viewed, are not easily comparable to those of print materials. Therefore, the study results could be skewed slightly because the user already had access to the e-book version through the existing NetLibrary collection and may not have used the print title through circulation, ILL, or in-house browsing as a result. This question will need to be addressed in future studies to further refine the method discussed in this paper.

Furthermore, an increasing number of e-book titles are available to individuals for purchase through commercial book providers such as Amazon. A potential future study could research the number or subject fields of those titles in the study sample that are available only through such e-book providers for individuals, but not for libraries, and how it will affect future library collection development.

\section{Conclusion}

The e-book market remains uncertain and inconsistent. Publishers that offer e-book equivalents are at considerable variance over the timing of the release of various editions of their titles, and aggregators face issues that can further complicate when an e-book becomes available. Publishers naturally seek to maximize the profitability of their output and, in the same way that they seek to calculate when to release paperback editions of titles, they now must consider the timing of e-book releases. Aggregators must deal with a multitude of publishers who are not consistent in the degree to which they will allow aggregators to license or transform their content for resale. Standard licensing terms are still emerging. Added to this are delays encountered by aggregators in the course of converting and enhancing publisher e-book files to accommodate the needs of their reading platforms.

Earlier studies focused on performing a usage analysis of e-books from a limited baseline of existing titles in e-book format. By contrast, this study reviewed the state of e-book growth as a part of the fast-changing 
world of academic publishing and looked at possible ways to incorporate e-books into academic library collections alongside, or in place of, print materials. The study took print materials as its starting point, assuming that their usage is a metric for overall demand, and investigated the proportion of that demand that can be satisfied by e-books. The authors asked two questions: "Can monographic e-content offered by providers supplement or even supplant local print usage?" and "Is e-book acquisition able to meet the needs of users? How?"

The study used circulation records, ILL requests, and in-house use records for print titles as a gauge of patron demand. The authors compared these records over the past three fiscal years to e-book offerings of two major e-book vendors. The authors found that 20.9 percent of titles that circulated three or more times were available as e-books, 23.5 percent of titles requested via ILL were available as e-books, and 31.4 percent of titles used four or more times inhouse were available as e-books. The resulting data were analyzed by publication date and subject area. While the results showed that e-book coverage was growing dramatically over the recent years, they also suggested that that e-books might meet only a part of the existing user demand for monographic scholarly output and that TCNJ Library could not yet rely on e-book content to entirely supplant print. The authors also found that e-book content that might meet users' needs was not uniformly distributed across subject areas. While the ratios of demand to e-book equivalence vary by LC class, e-book equivalents do not yet exist anywhere in sufficient depth to justify abandonment of print purchasing. The higher percentage of e-book equivalents was found in the ILL data, suggesting that this might be the best place to begin e-book collecting at TCNJ Library. However, the study results suggested that ceasing to collect print titles, at least for TCNJ Library, would be unwise at this time.

The value of this kind of bibliometric study is that it allows for an empirical assessment of demonstrated needs and thus can be correlated to local best practices in e-book collecting. This study outlined a flexible and easily reproducible quantitative method for determining how and in what subject areas e-books might best meet patrons' needs as defined by circulation, ILL, and in-house use behavior. The study offers insights not only into the potential of e-book collecting, but, as a by-product, can act as a gauge of the success of past print collecting. A review of the entire usage data set could be used to judge the effectiveness of past print purchases and to shape future budget allocations. It also could be used as a tool for deselection decisions. Looking ahead further, the methods used in this study also might be applied in a hypothetical patron-driven environment where some preselection takes place. Having ascertained the greatest areas of usage and e-book overlap, a library could shape its profile to feature these.

\section{References and Notes}

1. Lynn Silipigni Connaway and Heather L. Wicht, "What Happened to the E-Book Revolution? The Gradual Integration of E-Books into Academic Libraries," Journal of Electronic Publishing 10, no. 3 (2007), dx.doi.org.ezp2.lib.umn.edu/10.3998/ 3336451.0010 .302 (accessed Mar. 25, 2012).

2. Lucia Snowhill, "E-Books and Their Future in Academic Libraries," D-Lib Magazine 7, no. 7/8 (2001), www.dlib .org/dlib/july01/snowhill/07snowhill .html (accessed Sept. 2, 2011).

3. Justin Littman and Lynn Silipigni Connaway, "A Circulation Analysis of Print Books and E-Books in an Academic Research Library," Library Resources \& Technical Services 48, no. 4 (2004): 256-62.

4. Dracine Hodges, Cyndi Preston, and Marsha J. Hamilton, "Patron-Initiated Collection Development: Progress of a Paradigm Shift," Collection Management 35, no. 3/4 (2010): 211.

5. Millie L. Jackson and Beth Holley, "The Evolving Role of E-Books at the University of Alabama Libraries," Serials Librarian 61, no. 2 (2011): 200-206; Judith M. Nixon and E. Stewart Saunders, "A Study of Circulation Statistics of Books on Demand: A Decade of Patron-Driven Collection Development, Part 3," Collection Management 35, no. 3/4 (2010): 15161; Michael Levine-Clark, "Developing a Multiformat Demand-Driven Acquisition Model," Collection Management 35, no. 3/4 (2010): 2017; Doug Way, "The Assessment of Patron-Initiated Collection Development via Interlibrary Loan at a Comprehensive University," Journal of Interlibrary Loan, Document Delivery \& Electronic Reserve 19, no. 4 (2009): 299-308.

6. Hodges, Preston, and Hamilton, "Patron-Initiated Collection Development," 209.

7. Jackson and Holley, "The Evolving Role of E-Books," 202; Nixon and Saunders, "A Study of Circulation Statistics"; David C. Tyler et al., "Effective Selectors? Interlibrary Loan Patrons as Monograph Purchases: A Comparative Examination of Price and Circulation-Related Performance," Journal of Interlibrary Loan, Document Delivery \& Electronic Reserve 21, no. 1/2 (2011): 57-90; Jason Price and John McDonald, "Beguiled by Bananas: A Retrospective Study of the Usage \& Breadth of Patron vs. Librarian Acquired E-Book Collections" (presentation, Charleston Conference, Charleston, S.C., Nov. 5, 2009), ccdl.libraries.claremont.edu/cdm/singleitem/ collection/lea/id/177 (accessed Feb. 19, 2012); William Breitbach and Joy E. Lambert, "Patron-Driven Ebook Acquisition," Computers in Libraries 31, no. 6 (July/Aug. 2011): 17-20.

8. Jim Stemper and Susan Barribeau, "Perpetual Access to Electronic Journals: A Survey of One Academic Research Library's Licenses," Library Resources of Technical Services 50, no. 2 (2006): 91-108.

9. Lindsey Schell, "The Academic Library E-Book," in No Shelf 
Required: E-Books in Libraries, ed. Sue Polanka, 75-93 (Chicago: ALA, 2011).

10. Snowhill, "E-Books."

11. Ibid.

12. Carol A. Mandel, Mary C. Summerfield, and Paul Kantor, Online Books at Columbia: Measurement and Early Results on Use, Satisfaction, and Effect (Washington, D.C.: Association of Research Libraries, 1997), www.arl.org/resources/pubs/scat/ mandel-2 (accessed Feb. 19, 2012); Susan Gibbons, "netLibrary eBook Usage at the University of Rochester Libraries," version 2, Sept. 27, 2001, www.lib.rochester.edu/main/ebooks/ analysis.pdf (accessed Feb. 19, 2012).

13. Allen McKiel, "ebrary's Global eBook Survey: Survey Analysis," June 11, 2007, site.ebrary com/lib/librarycenter/docDetail.action? docID=80000723 (accessed Feb. 24, 2012).

14. Connaway and Wicht, "What Happened to the E-Book Revolution?"

15. Wendy Allen Shelburne, "E-Book Usage in an Academic Library: User Attitudes and Behaviors," Library Collections, Acquisitions \& Technical Services 33, no. 2/3 (2009): 59-72.

16. Nancy Sprague and Ben Hunter, "Assessing E-Books: Taking a Closer Look at E-Book Statistics," Library Collections, Acquisitions \& Technical Services 32, no. 3/4 (2009): 150-57; Robert Slater, "E-Books or Print Books, 'Big Deals' or Local Selections-What Gets More Use?" Library Collections, Acquisitions, d Technical Services 33, no. 1 (2009): 31-41.

17. Littman and Connaway, "A Circulation Analysis," 256.

18. Rusty Kimball, Gary Ives, and Kathy
Jackson, "Comparative Usage of Science E-Book and Print Collections at Texas A\&M University Libraries," Collection Management 35, no. 1 (2010): 15-28.

19. Ibid., 15 .

20. Martha Kyrillidou and Shaneka Morris, ARL Statistics, 2008-2009 (Washington, D.C. : Association of Research Libraries, 2011).

21. Judith M. Nixon, Robert S. Freeman, and Suzanne M. Ward, "Patron-Driven Acquisitions: An Introduction and Literature Review," Collection Management 35, no. 3/4 (2010): 119.

22. Nixon and Saunders, "A Study of Circulation Statistics."

23. Tyler et al., "Effective Selectors?"

24. Gayle Rosemary and Y. C. Chan, "Purchase Instead of Borrow: An International Perspective," Journal of Interlibrary Loan, Document Delivery \& Information Supply 14, no. 4 (2004): 23-37; Suzanne M. Ward, "Books on Demand: Just-in-Time Acquisitions," Acquisitions Librarian 14, no. 17 (2002): 95-107; Suzanne M. Ward, Tanner Wray, and Karl E. Debus-Lopez, "Collection Development Based on Patron Requests: Collaboration between Interlibrary Loan and Acquisitions," Library Collections, Acquisitions, \& Technical Services 27, no. 2 (2003): 203-13.

25. Tyler et al., "Effective Selectors?"; David C. Tyler et al., "Just How Right Are the Customers? An Analysis of the Relative Performance of PatronInitiated Interlibrary Loan Monograph Purchases," Collection Management 35, no. 3/4 (2010): 162-79; Way, "The Assessment of Patron-Initiated Collection Development."

26. Uta Hussong-Christian and Kerri Goergen-Doll, "We're Listening:
Using Patron Feedback to Assess and Enhance Purchase on Demand," Journal of Interlibrary Loan, Document Delivery \& Electronic Reserve 20, no. 2 (2010): 319-35.

27. Tyler et al., "Effective Selectors?"

28. Nixon, Freeman, and Ward, "PatronDriven Acquisitions," 121.

29. Way, "The Assessment of PatronInitiated Collection Development"; Kyrillidou and Morris, ARL Statistics, 2008-2009; Andrew Leykam, "Exploring Interlibrary Loan Usage Patterns and Liaison Activities: The Experience at a US University," Interlending \& Document Supply 36, no. 4 (2008): 218-24.

30. Hodges, Preston, and Hamilton, "Patron-Initiated Collection Development"; Breitbach and Lambert, "Patron-Driven Ebook Acquisition"; Jackson and Holley, "The Evolving Role of E-Books."

31. Price and McDonald, "Beguiled by Bananas."

32. Jason Price and John McDonald, "To Supersede or Supplement: Profiling E-Book Aggregator Collections vs. Our Print Collections" (presentation, Charleston Conference, Charleston, S.C., Nov. 7, 2007), www.slideshare .net/john_modonald/charleston2008ebook3 (accessed Apr. 20, 2012).

33. Sarah Pomerantz, "The Availability of E-Books: Examples of Nursing and Business," Collection Building 29, no. 1 (2010): 11-14.

34. F. W. Lancaster, The Measurement and Evaluation of Library Services (Washington, D.C.: Information Resources Press, 1977).

35. Way, "The Assessment of Patron-Initiated Collection Development." 